REAFFOFEGTATION EFFOFTS INSIDE AFGHAHISTAN

Submitted to:

Duke Miller

Internaticnal Fiescue Committoe

Self-Feli ance Frogramme

by:

Maomi Minwa11a

August 24, 1989 
TAELE OF CDNTENTS

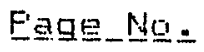

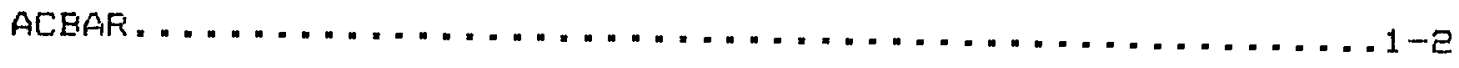

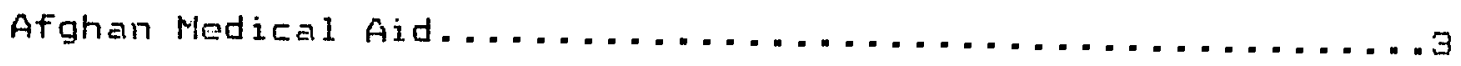

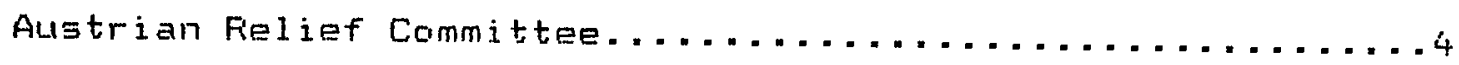

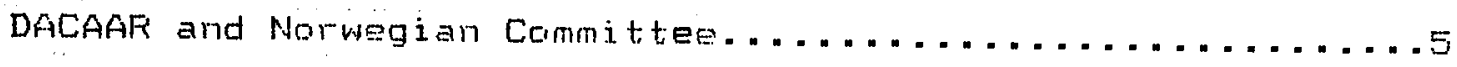

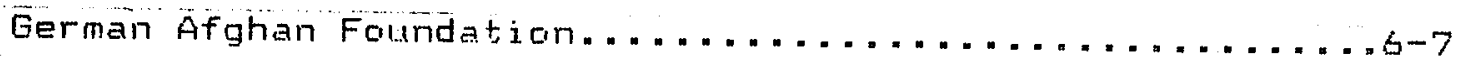

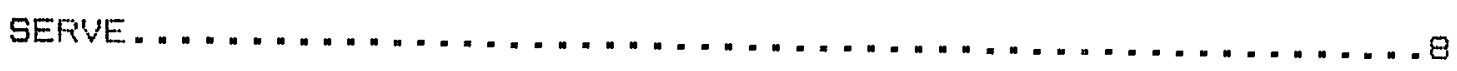

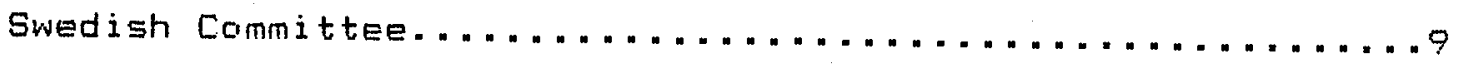

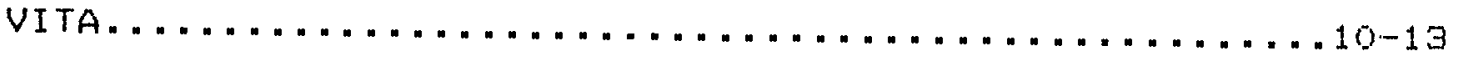

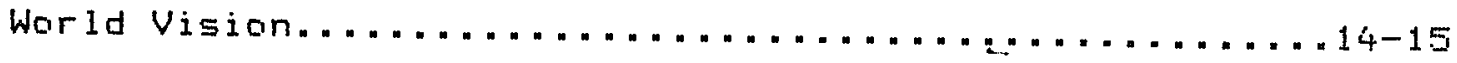

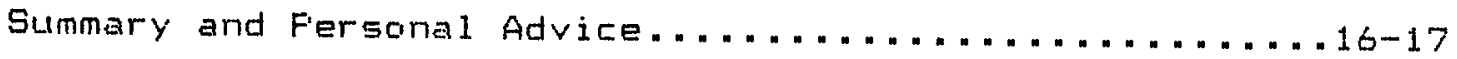

Statistics on Fattia (Obtained from Faul Heinzen).......18-es

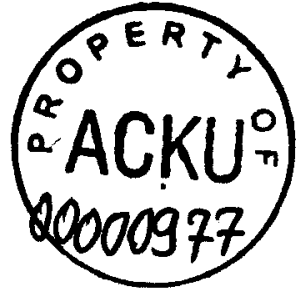


The purpase of this paper i= to provide the Internetional Fescue Committee's Self-Feliance Fragramme ard any ather interested parties with brief advice and information on reaffarestation in Afghanistan. Its major rocus i tress. Every section is a summary (addressed to Dule Millew) of personal meetings held with the peaple nemed at the tap af each page. Some statistics on Fartia are also at ached. The repartis by no means complete, as maiy HGOs were unavailable bo tall: It: should, however, serve as a good starting point for those who are interested in implementing reafforestation progrannes and cocrdineting activities together inside Afghanistan.

Nomi linwa 11 a 
ACEAR Ag-iculture Sub-Committee Meeting

Dr. J. Cartwright, FAO Consultant

"Fruit Tree's for Afghanistan"

Alugust 09,1989

Periodically, representatives from various NoDs gether at ACBAR to coordinate aģricultural activities for Afghanistan. Each meeting has a different topic and everyone is free to ask: questions and mafe comments. It would be advisable for you and ... Sharif to attend as meny of these meetings as fossible. Nadette Foley at ACBAR can provide you with a sthedule.

Presently, FAO has fruit projects in Quetta and Gilgit. They will be taking fruit tree orders by the end of september. FAD funds are 1 imited to rehabilitation, and your order should reflect this. The logistics will hawe to be well-organized. After waiting two days for the tree's to be del ivered in peshawar, the NGO must be prepared to send then straight inside Afghanistar.

Much of Mr. Cartwright's discussion was concentrated on apple trees. Perhaps this is because they are known for giving very quick returns. He reminded everyone to make sure that pollinators are purchased to go along with any apple tree orders. He also advised against purchasing any apple trees from Ewat because there has been 3 problem with disease. (With the exception of $\mathrm{Dr}$. Wakhil's nurseries?.

FAO's fruit trees will come from ouetta and include apple, apricot, peach, pommegranate, and plum. They do not have any citrus trees available. If you are interested in ordering, you must know the required types and quantities by the end of September.

The need to establish nurseries by sending root stocks into Afghanistan was stressed. Number 100 Root Stock (Semi-Dwarf or Dwarf) is recommended. The fact that most of the Semi-Dwarf trees have been the first to disappear in Afghanistan could cause problems with the farmers who are now reluctant to accept SemiDwarf root stock. It was suggested, therefore, to have demonstration plots with equal proportions of Dwarf, Semi-Dwarf, and standard root stocks. The farmers will then be able to observe and decide which type they would like for themselves.

According to FAO, fifty percent of the orchards in Afghanistan are not worth keeping anymore. Since many of them will have to be dug up, it is important to get sufficient vigour into the soil system. A combination of manure and soil would be adequate. Growth regulators should not be used until later. 
Mr. Cartwi ight has been in touch with a consultant in Turkey regarding Poplar trees. A mixture of clones is necessary, and the trees should be in Afghan murseries for approximately one year before being distributed to the villages. Keeping some nurseries in Pakistan for "safe keeping" should also be considered. The Forest Institute of Patistan is a good purchasing source. FaO will also be conducting a pilat project for Black Poplar trees from Turkey (50,000 cuttings). These trees are unavailable in Pakistan and are more suited to cold temperatures and high altitudes.

Dur ing-the meeting, Di-. Walhi i commented an two of his major concerins. Firsty, he stressed the importance of "Quslity

Control." In order to prevent trees from going in with posts or diseases, there must be some form of policing. Purchising trees from FAD gives NGDs an assurauce that they are receiving healthy plants. Secondly, it is important to mix the tree varieties. In order to earn money, farmers will select the right variaties for their particular region. We must choose the assortments that will bring good incomes to the farmers. Ihsanalluh recommended that a task force be organized to set quidelines for what trees are needed and where they are reeded in ffghanistan. The group subsequently elected Ihsanalluh to head this task force.

FAD will also offer training sessions this winter in Peshawar: and Quetta. The instruction will be of two types:

1.) Practical - Designed for the basic farmer. How to use fertilizer, spray pesticides, etc.

2.) Focal - For the more experienced farmer. How to identify pests and diseases, what type and how much spray to use, etc.

If you need any other information from FAO, you should contact Anthony at the UNOCO office in Islamabad. His eitensions are 213 and 212 . You may recall our luncheon meeting with him and Paul at my house last month. 


\author{
Afghan Medical Aid \\ Dr. Sahary \\ 43283
}

Dr. Sahary has a Phd. in Animal Science and worked for ten years in Ankara, Turker. He also studied agriculture in funar. Afghanistan. -His research focuses on runar, where most forest: in Afghanistan are located.

According to Dr. Sahary, reafforgstation in Afghanistan should be started with fruit trees. Mulberries, oranges, and silver beries (a dry fruit which is not availabie in Palistan) were the first types to come to his mind. In addition, walnuts and grapes would be good for commercial trade.

After Paktia, he recommended that we start reafforestation in lunar because it is enemy-free (runar was the first province to be completely controlled by the mujahideen). The prowince is also located close to bases in Palistan conly five driving hours away). I sensed that his recommendation was also based on the affinity that he has for the province. It is, after all, the region which he comes from.

Aside from the above information, Dr. Sahary was not able to provide us with any other linowledge on reafforestation. Dur discussion was short, and 1 don't think that sharif waj very impressed with him. 


\section{Austrian Felief Committee \\ Kathy Kaldor \\ Nopi Saraj \\ 41129}

This report may be repetitive for you since both of us were present at the meeting with Nobr Saraj. Mevertheless, you may hotes might prove to be useful vacationing in Thailand and ny

Funded by UNHCR, The Austrian Relief Comittes' = (ARC) nursery programme is geared towards widowed women refugess who are eager. to learn and work, but who lack the necessary skilla to income, this programme providing the women with a source of rebuild their self-confidence.

One week: was spent doing surveys in the refugee camps. After finding that the soil wis at an unacceptable level, ARC fertilizer. Two types women with free soil, sand, tools, and Forest Institute-- Leucina bought from the Pakistani bear fruit, as they are mainly used for feither of these trees grow in both Pakistan and Afghanistan. fuel and shade. They

Before distributing the seeds, AFC held a ane month training session to teach the women how to punch holes in the bags and to $\mathrm{mix}$ the fertilizer and soil. The trainers reached sixty-nine houses, with each house getting eight to ten training sessions.

The project was initiated in September, 1988. Soil was distributed in December, 198e, and the seeds (a total of $100,058,700$ with approximately 2,500 going to each fanily and in daily contact with the April, 1989 . ARC's field officer's are progress. Every two months they and keep good records of their healthy plant that she's nui-they pay a woman 25 paisa for each two months). At the end of orred (apptoximately bes rupees every every healthy plant. The see one year, ARC will pay 50 paisa for Pakistanis or other. The seedlings will then be sold to the Afghanistan. Al wo would like to transfer them to projects.

Surprisingly, no problems have arisen with the elders in the camps. Given the conservative nature of the Afghan culture, it women as well. 
DACAAR

A.B. Afzali

43084
Norwegian Commit tee Khowaja Mohammed 42517

DACAAR and the Norwegian Comititee are working together for reafforestation projects inside Afghanistan. DACAAR would like to work primarily in Kunar and has recently submitted a proposal to UNHCR. They plan to use seedlings from the Norwegian

Committee until their funding comes through and they are able to establish their own nurseries. Phase II of DACAAR's plan is to complement their road construction programme in Paktika sith road-side reafforestation.

The Norwegian Committee has already established nurseries in Kunar. All of the necessary seeds and inaterials (including the plastic bags) are bought in Chowk-Yadgar, Peshawar. So far, they are growing three to four hundred thousand seedlings comprised of Eucalyptus, Evergreen, some kind of Mulberry, and Acacia. They are also planning to grow apricots, peaches, applas, and pommegranate. These seedlings will be distributed free of charge.

Although their work is not directed towards Paltia, these two men are still good sources for information. Their coordination efforts should set an example for all other NGOs to
follow. 


\author{
German Afghan Foundation (GAF) \\ Mr. A. R. Ginaforri \\ 43257
}

Although the German Afghan Foundation is very interested in starting a reafforestation programme for Afghanistan, thei, (WFP) were unsuccessful. considered to be "emergency fact that ragforestation is not to receive. Although WFP disistance" makes funding diffict: 1 t alternative, it was very did offer GAF a "Food for liprkilos of wheat per day for each forner offer of providing 3.5 even consider. This year. WFF may increase their of for GaF to kilos of -wheat If $\equiv 0$, Gaf will probably tegin the offer to seven Paktia using the "Food for Wark" approach.

In Afghanistan, there has been no contol over cutting and selling trees for income. With this in mind, Mr. Ghafoori highly recommends starting with fruit trees which yield a fixed retirn. In Paktia these include apples, peactes, almonds, walnuts,
apricots, cherries, pears, and grape's.

Even though seedlings can easily be purchased donestically (i.e. Swat, Chitral, Gilgit, Kashmir, Mansehra, Murres, Mr. Ghafoori is firmly against having the nurseries in Paltistan. His
reasons are as follows:

1.) Transportation from Pakistan to Afghanistan may

e.) Cause physical damage to the plants. Abrupt changes in the climate may have adverse effects. For example, Pahistan is sub-tropical, while Palitia is temperate.

3.) The $r i s k$ of transferring diseased plants into Afghanistan is too high.

4.) Once repatriation starts, having the rurseries inside Afghanistan will encourage more people to
return.

Most farmers in Afghanistan are experienced enough to grow will be required. Demonstration their region. Minimum assistance will be required. Demonstration plots should only be used for has never been exercised in bags to lieep the roots in $p$ Afghanistan is the use of plastic and safer replanting and must be introduced allows for easier

The adopted infrastructure is dependant on the region which the NGO is working in. If a good commander is available, he should be the person to work with. Otherwise, the local shura (not locals) in the area is also recommended. 
Fruit trees should be sold at a subsidized price to the poorest farmers. Forestry tree's (i.e. Pine, Poplar, farmers. If these cannot be sold provide a fixed income to the should be distributed free of charge. subsidized prices, then thay

Mr. Ghafoori is an intelligent, experienced whose advice is well-worth accepting. will probably implement his project in Paktia, I fact that he recommend that you contart him before commencing inould strongly in that area. Coordinating everyone commencing IRC progr.ammes 


\section{SERVE \\ Ross Haliburton \\ 43253}

Presently, SERVE has a total of 140 small nurseries in seven villages of Pakistan. Last May, they started setting up nurseries in Kunar. Afghanistan. Dnae oxtra funding $i$ s made available. they would also 1 ike to open up nurseries in Mangahar. Since funding requests to UNHCR were declined, most of the money for their nurseries comes from charities in the united kingdom.

In the Pakistan programme; seeds are distributed to the people free of charge. The manure, sand, and soil mu:t be provided by the people themselves. Two field office:s are assigned to supervise the nurseries and their last monitoring report stated that about thirty percent of the nurseries were in "very good" condition, while fifty percent were "average." This is not an acceptable outcome for SEPVE. and they may have to consider supplying more inputs to the poorer refugees. Dince the seedlings are ready to be transplanted, the refugees are free to choose whether they want to sell or distribute them. The richer refugees are expected to give them away, while the poorer ones can sell and make a profit of one to two rupees per tree. New refugee arrivals have been very keen to buy them.

Since it is the freest province, funar was chosen as the first area in Afghanistan to implement nurseries. Fuel wood was the major reason for initiating the project, but the people also requested shade trees. SERVE now ha's one man in kumar who has been setting up nurseries with Eucalyptus and Leacuena seeds since last May. No monitoring has been done yet, so the records of progress are unavailable. The seeds are given to the farmers free of charge and it is up to the Shura to decide whether the seedlings should be sold or distributed.

Since both IRC and SERVE may be interested in starting future nurseries in Nangahar, you will be contacted once seRve receives the funding. Mr. Haliburton seemed very eager to maintain contact and coordinate activities with rou and Sharif. 


\title{
Swedish Committee
}

\author{
Agricultural Surver of Afghanistan \\ Azam Gul \\ 42719
}

Dur discussion with the Swedish Cominit tee was very short. At present, they have no reafforestation programme. Azam Gul is an agronomist, so his knowledge on fruit trees is linited. He recommended getting furthar advice from Dr. Wakhil.

According to Azam Gul, any NGO starting reafforastation projects in Afghanistan must be aware of the dangers of disrupting the farmer. Careful research must be don: in advance to ensure that the tree is adaptable to the area which the NGO is working in. Since the time lapse before fruition tates plare can be as long as five years, farmers run a high risk from growing fruit orchards and must receive some sort of supplemental income. Also, if the wrong type of tree is given from the onset, the farmer may not only lose his fruit $y i=1 d$, but his own selfconfidence as well.

Azam Gul is against giving the seedlings free of charge. Field officers should be sent in to study the area and decide what method should be used for repayment. Likewise, a study should be done before deciding shether to worli through a shura or a commander. 


\section{VITA \\ Dr. Wakhil, Tecnical Advisor for Agriculture $44518 / 42977$}

This British-sounding Afghan is the most respected agriculturalist in the community. Nome of my discussions ivith other NGOs went wi thout mention of his name. His intallestual would highly recommendes make hin a creatble resourea, ard I implementing any reafforestatiou take his advice before

him was lengthy, but all very relevant.

VITA presently has two types of plantations-- waddots and horticulture. Both of these are out lined below.

I. WOOD LOTS

Dr. Walihil's wood lots are comprised of forest trees planted along water channels located in Logar, Ghazni, and Wardak. The three types of trees and reasons for using them are as follows:

a.) Mulberry: Every farmer in Afghanistan would lilie to have a Mulberry tree. (It's not just the vocal group which has made this tree fashionable!!!) Many have disappeared with the mar. The major benefits are that it is fast-growing, bears a fruit, and provides fuel and shade.

b.) Poplar: The Poplar tree is also fast-growing and has mainly been used for shovel handles. Each family in Afghanistan has at least three to four shovels. The problem, however, is that the wood is not very strong. The shovel handles must be very thick and are, therefore, heavier than they need to be.

c.) White Ash ("The Normal Ash"): This is a new variety for Afghans. It is strong, has smooth stems, and would act as a good replacement for the Poplar shovel handles. Both the United States and Europe use it in their production of shovel handles. While maintaining the same strength, a White Ash shovel handle is half the diameter of a Poplar handle. 
Dne of the major benefits of using fruit trees and orchards is the employment that it provides for the people. According to Dr. Walthil, fruit trees in the long-run will provide more income to the farmers than wheat. 5ome people will some people claim that wheat, but $D r$. Wakhi disparage farmers from growing would be a problem.

Dr. Walkil would like to start growing three major fruits and nuts inside Afghanistan. These are grapes (with orip irrigation), apricots, and almonds. Both the grapes and the apricots can be dried, stored, and marlieted at convenient times. They have big international marlets and 5 an grow well in many parts of Afghanistan. Accorsing to Dr - Wakhil, Afghan raisins, in particular, have a "name in the world." For vegetables, he recommends growing potatoes, cauliflower, peas,

The most interesting topic of our conversation bas the use of Russian Dlive trees for borders around crops. Although most Westerners have never heard of this tree, it has always been used are costly, deplete to protect crops in Afghanistan. Mud walls away. For the reasons listed soil, and may eventually $3 a s h$ serve as an excellent boundary.

1.) Fast growing.

2.) Withstands drought and water logging. It can be

3.) Grown wi thout irrigation).

4.) Has thorns.

5.) It is not a shade tree and can, therefore, grow

6.) Does not have a big root system, so there is no chance of damaging the crops.

7.) Best suited for hedges around orchards.

8.) Can be used for fuel. The branches are easy to

9.) burn even when they are green.

Bears a fruit similar to an olive. (overweight people will be pleased to linow that the fruit is
sweet, but low on calories!!!)

Plant cuttings should be placed $5 i x$ to eight inches apart. Seedlings should be planted one foot apart.

Dr. Wakhil's proposal for distributing the fruit cuttings/seedlings is well thought-out and deserves complete attention. A summary of his criteria for each of the farmers 
1.) Use Russian Dlive trees as borders.

2.) Each farmer must have a proper layout to avoid planting haphazardly.

3.) Farmers can only grow fruits and vegetables. orchard.

5.) Farmers must be permanent residents in Afghanistan. (i.e. They cannot move back and

6.) Farmers between Afghanistan and Pakistan). (libe a bicycle pumpl that the farmer must. This is the on? thing

B.) Constant monitoring. Purchase himself.

9.) The Shur will be

10.) Manimum distribution 5 ignatory in the contract. (approximately serious farmers three jeribs). Those who are

11.) The Semi-Dwarf trees will ive more after one year. free of charge, but in one of two ways:

a.) A farmer will be charged if he does not take care of the trees.

b.) Along with the trees, each farmer will be responsible for tending to nurseries. If, for example, a farmer had received 500 trees. from UTA, then he would also have to grow 500 seedlings. These seedlings will be returned to VITA when they are ready for
transplanting.

Dr. Wakhil disagrees with those who believe that the trees should not be given away free. His project is aimed at small farmers with limited resources. In Afghanistan, one apple tree costs 250 Afghanis. The people simply cannot afford such high prices. The nursery scheme mentioned above would restore any "pride" lost from receiving the cuttings/seedlings gratuitously.

Getting people to grow and care for trees in development work is difficult because there is no return in the short-term. According to $\mathrm{Dr}$. Wakhil, at least three years will pass before will not be reached until income from the fruit trees. Their peak farmers for using their land for year. To compensate the risk, VITA will give each farmer a more long-term investment 
archard is still in good condition by the middle of every growing season.

It is apparent that Dr. Wahil's proposal would serve as an excellent guideline for other reafforestation projects inside Afghanistan. I am certain that he would talk with you at greater length about any queries you may have. He is very approachable and eager to help anyone involved with the reconstruction of his homel and. 


\author{
World Vision \\ Peter Crichton \\ Agricultural Consultant \\ $42431 / 43803$
}

Peter is new in Peshawar and is working with World Vision's Rehabilitation Programme inside Afghanistan. Since most of his warking time is spent in Chankeni, Paktia, his advice comes primarily from "first-hand" experience.

According to Peter, there is an obvious need for reafforestation in Paktia. In addition to low-level water tables and danaged irrigation canals, many animals and bees are dead. Villagers are, therefore, forced to turn to defforestation for income generation. Acute defforestation in the higher regions could cause flash floods in the south if heavy rains occured. With this in mind, reafforestation should be started in the higher hills first. A project such as this will be huge, as millions of trees will be required.

Although Peter connects reafforestation mainly with forest trees, he does believe that fruit trees serve as a grod "introduction" for the people. He has seen apple, peach, and walnut tree's growing in the region. Last Spring, Horld Vision sold 3,000 fruit trees at subsidized prices. The trees were originally bought in Swat at fifteen rupees per tree and sold to farmers in Paktia for two rupees per tree. Associating a value with the trees is very important.

Reafforestation, according to Peter, is not a "technical" problem, but a "socio-political" one. Many of the commanders in the region are directly involved with the forestry extraction. (With proceeds probably going towards jihad). Al though a shura is also present in the area, most of the commander-s dominate it. Permission for any type of activity in the area will have to be taken from the shura.

Before beginning a fruit tree project in Paktia, four major points of thought arise. Firstly, the nurseries must be located in Paktia. Peter has already seen some walnut nurseries in the Chankeni region. Secondly, there must be a market for the fruit. Thirdly, the logistics must be well-organized. If there is a market, then where is it and how will the fruit reach it? Lastly, since it usually takes three to four years before the trees reach fruition, an NGO must be prepared to pay a supplemental income to the farmers.

Since World Vision is already operating in Paktia, it would be advisable to speak with them before starting any new projects 
there. Peter mentioned that coordination between world Vision and IRC in Paktia was part of a contract signed by the two agencies. Contract or no contract, we all fnow the inportar importance of problems have arisen between the my discussions with their perso organizations in the past, World $V i s i o n$ employees that eager to work together with IfC in fakt in touch with seem very 


\section{SUMMARY_GND_EEEFSQNAL_ADVIEE_TQ_DUEE_MILLLEE}

After spending only eight days gathering data on reafforestation. I can in no way pretend to be an expert in the field. I would, however, Iike to add same of my personal advice as well as reiterate some of the major points which were brought up during the meetings.

1.) Survering: Please contact Engineer Zahir at the FFA office about this. Fresently, FFA is sending in agricultural survers, and I requested that questions about reafforestation be included in them. Engineer Zahir would like to speak with you about this as sogn

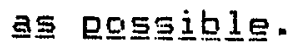

2.) You and Sharif should go to as many ACBAR Agriculture Sub-Committee meetings as possible. updated on all of the agricultural community and also help you establish

It will kesp you activities in the mare contacts.

3.) Although you were mainly interested in keeping the nursery seedlings in Fakistan for transport inta Pal:tia, I am convinced that most of the nurseries should be inside Afghanistan. FAO's idea of only operating a few nurseries in Fatisten for "safekeeping" is well-advisable. Possible problems with transportation, climate changes, and disease were the major reasons for not having the nurseries in Fallistan.

4.) The programme should be started with fruit trees which provide Afghan farmers with a good return. You must also be prepared to supplement the farmer" with some sort of income until fruitian occurs.

5.) Keep in good contact with Dr. Wakhil at VITA. He seems to be the "sole authority" on this subject.

b.) Coordination with other agencies is extremely important. For example, we know that world visian and The German Afghan Foundation are also trying to work in Paktia. You should meet with them before laying out any plans. The same goes for DACAAR in Faktika and SEFVE in Nangahar.

7.) It is apparent that many funding sources equilibrate reafforestation with "development work" and not "relief work." Several reafforestation proposals submitted to UNHCF were subsequently declined. Although it is always worth trying every possible funding source, I would also recammend that you look for "new danors" who 
7.) (Cont'd.)

may be more inclined to fund long-term projects such as this. Possible scurces are the World Eant: Asian Development Bank, and the Dverseas Development Agency.

EOOD LUCK!! 


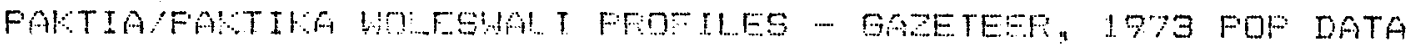

\begin{tabular}{|c|c|c|c|c|c|}
\hline$n+5$ & Te- $14=$ & $110 t e=A 1$ & 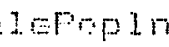 & & \\
\hline 939 & 4090 & 2450 & $2070 \%$ & $41+18$ & 115 \\
\hline $4 \geq 7$ & 219419 & 1750 & 1.9690 & 37100 & 44 \\
\hline 410 & खीम & 1750 & 21937 & 43374 & $7 e$ \\
\hline 163 & वाis & $1 \leq 50$ & 7097 & 14194 & 40 \\
\hline 264 & $131 \%$ & 1700 & 12033 & 25066 & 71 \\
\hline 420 & 20212 & 1250 & 40612 & 6024 & $1 \pm 1$ \\
\hline 427 & 219.99 & 1905 & 35210 & 70400 & 49 \\
\hline 405 & 20115 & $1 \div 0$ & 20135 & 40270 & 38 \\
\hline 411 & eण: & 287 & 393 & 7676 & 21 \\
\hline 58 & 1.29946 & 1700 & 4370 & 9740 & 19 \\
\hline 917 & $4=250$ & 2150 & 40041 & $860 \theta$ & $1 E 7$ \\
\hline 35 & $19 \% 17$ & 1350 & 10690 & 97256 & 74 \\
\hline 175 & 9469 & 1803 & 699 & 12790 & 25 \\
\hline $5 \%$ & कet? & $21 \%$ & 1795 & 25150 & 36 \\
\hline 510 & क्श & 1730 & $1=78$ & 2550 & 43 \\
\hline 3.3 & 2540 & 180 & $28+5$ & $4+470$ & 60 \\
\hline 57 & 80109 & 2100 & 8170 & 4340 & 6 \\
\hline 200 & 19419 & 100 & 601 & 13122 & 20 \\
\hline $1=1$ & $75: 69$ & 200 & 419 & 8944 & eP \\
\hline $1 \%$ & $\because \%$ & 1600 & 6625 & 13250 & 15 \\
\hline 431 & e15:? & 2120 & 5190 & 10390 & 27 \\
\hline 607 & 15994 & eिe & 770 & 15430 & $1 e$ \\
\hline 40 & $0+100$ & 1075 & $1531=$ & 30630 & 42 \\
\hline $1 \div 2$ & 596 & 1280 & 27100 & 54360 & 36 \\
\hline $109:$ & 5177 & 1976 & 3154 & 69300 & 55 \\
\hline 27 & $\mathrm{w}^{\prime}+4$ & 2150 & $104: 9$ & 20910 & 33 \\
\hline$\cdots=$ & 6िय & 897 & 3760 & 33590 & 14 \\
\hline $1 \%$ & 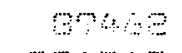 & $5 \%$ & 5997 & 10794 & 19 \\
\hline $6=9$ & 9290 & 8000 & $3=990$ & 70780 & 42 \\
\hline 49 & अ 196 & 1015 & 4046 & 9670 & 1308 \\
\hline
\end{tabular}


Sayed fian Jedran

Nesa rinel

Danda Fatan

Chamtiani

khost

Tani

NaderShahtot

Sarobi

Laja Mangal

Eormat

Jaji Maydm

Eat:

Urgoon

Sperah

Sabari

Dara-I-Daran

Curbuz

Dalandar

Shama 1

Mata than

Dima (Drma)

Terizai(Ali-

Tardo $z a i$

Barna 1

Eayan

Sarhatea

Mela

Gardiz

TOTALS
Foplto 3rFarmeregropoland

60164

59663

70405

Eอ7\%?

411.65

135760

113003

$648=?$

12318

$140=5$

$1374 \%$

59705

20504

56405

4100

$71=9$

6944

2105

$139 \%$

ㄹ.

$1665 \%$

e4041

49150

g7ase

109614

$355 \%$

59790

17301

1:3591

1.5605

\section{$4: 200$}

$36 \div 1$

$132=1$

14129

eras

947?

700

icote

767

E6

907

3707

107

$94 ? 1$

erso

456

1310

1005

פक्ष

13103

$1025 \%$

1501

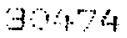

502

67.61

ents

39390

$10 \%=0$

70.6

$96 \%$ esifo

1067

10245

4073

6597

1045

10970

10121

10071

64.

อ2715

5971

‥ 373

14544

1.

7928

1404

$7<21$

3773

2978

10770

12670

10095

라

27099

4977

19117

443

16018

39428
Fra, Ith $1 d=J r b=/ F a r m H c t r / f a r m$

$$
2746
$$

3963

3969

1204

ㄹㄹ 1

7708

6559

3610

694

71

7750

3370

$115 \%$

$31 \%$

2.11

4024

393

$110 \%$

746

1150

937

1400

2770

4917

6178

$18 \%$

3032

97

6 6.

97707
6.3

3.2

ㄹ.

‥2

ᄅ. 8

1. 4

1.7

ㄹ. 9

14.9

9. 2

3.0

‥ 7

3.8

4.5

5.5

1. .9

3.6

Q. 1

5.1

3.3

1. 1.5

9.0

4.4

0.6

4.4

3.0

5.0

i. 6

ᄅ.

is. 7

0.9

.3

0.6

0.5

0.6

0.6

0.3

0.3

0.6

3.0

1.6

0.6

o.t

0.8

0.9

1.1

0.4

0.7

1.6

1.0

6.7

2. 3

1. $\mathrm{E}$

0.9

o. 1

0.9

0.7

1. 2

0.9

0.5 


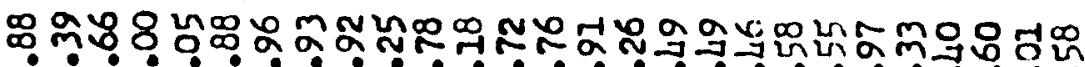

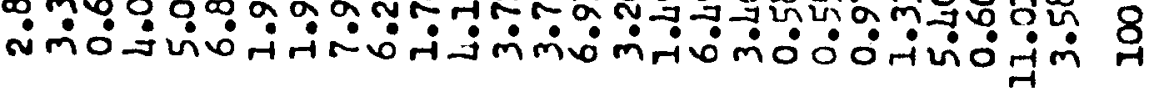

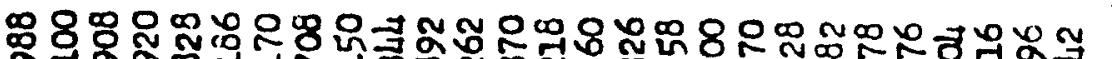

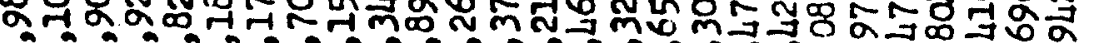

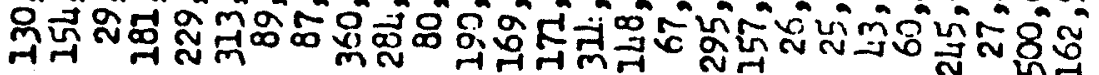

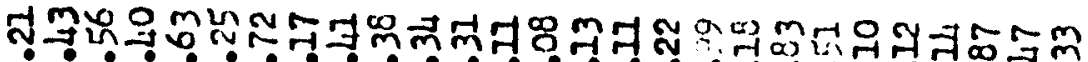

疍

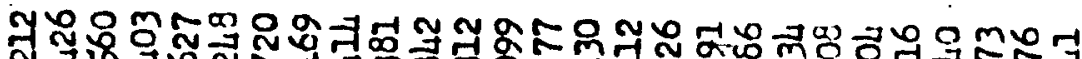

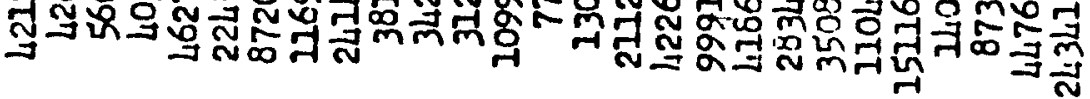

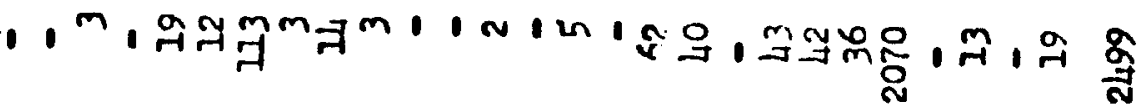

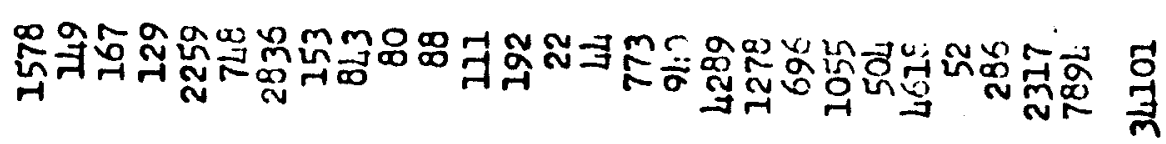

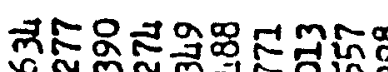




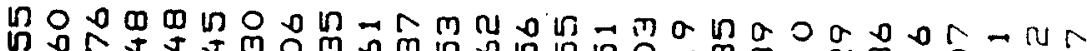

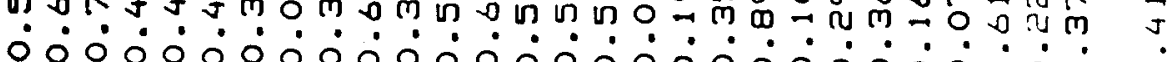

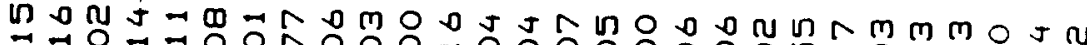
迨. 0 o L 象古古

$>$

tu

0 in

o 0

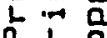

a. $\frac{1}{8}$

20

$>$

$\rightarrow \stackrel{+}{u}$

幽

o 0

- 1

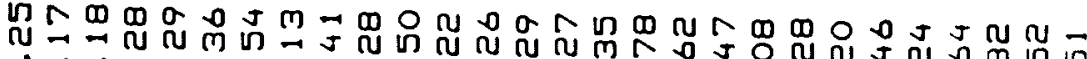

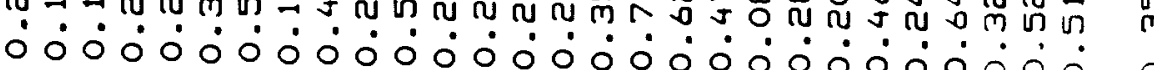

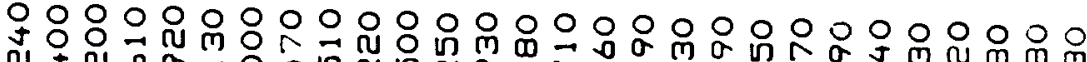
ญง ○。ल ญ

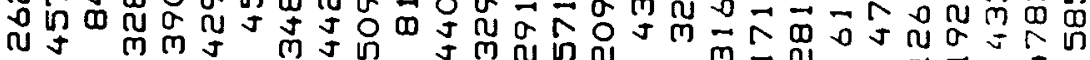

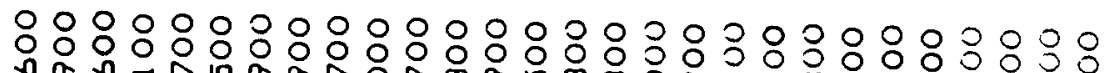

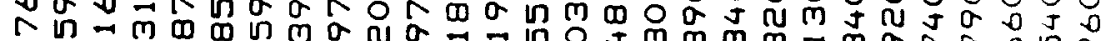
m

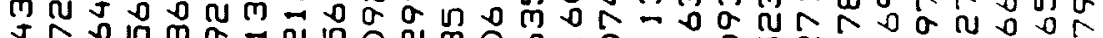

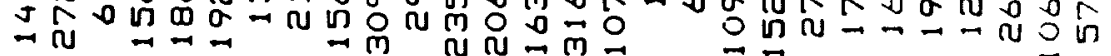

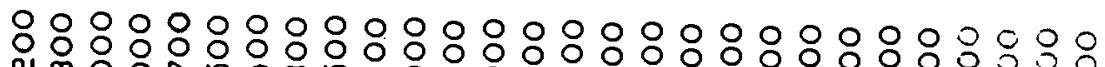

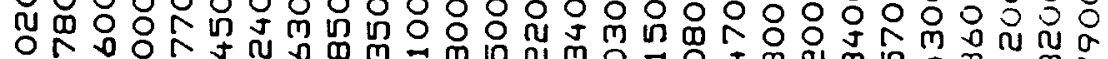

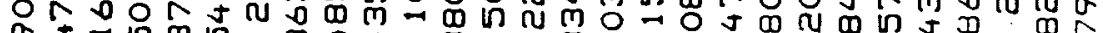

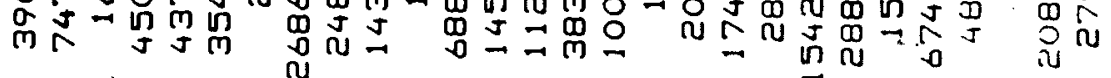

กำ .

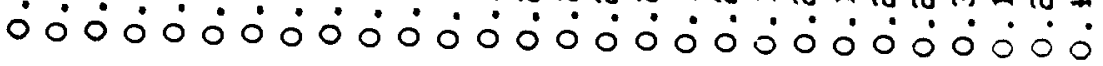

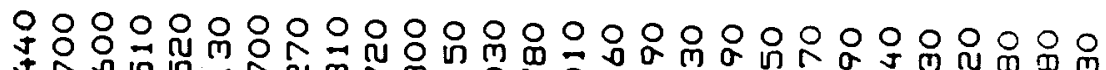

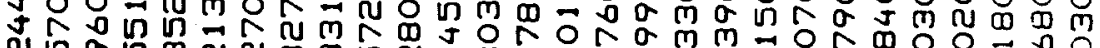

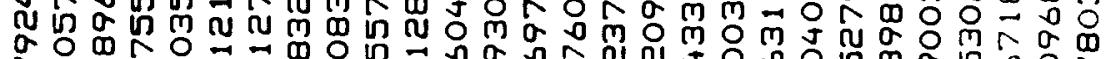

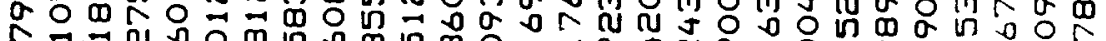

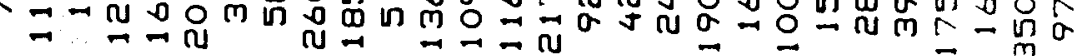

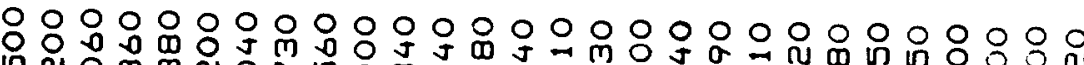

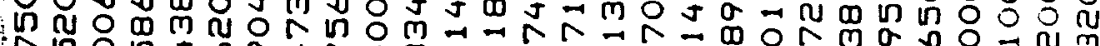

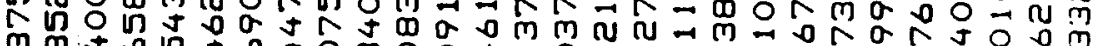

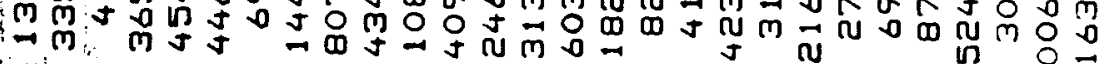

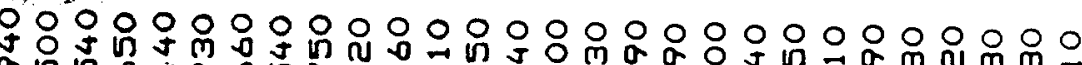
员

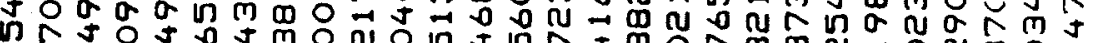

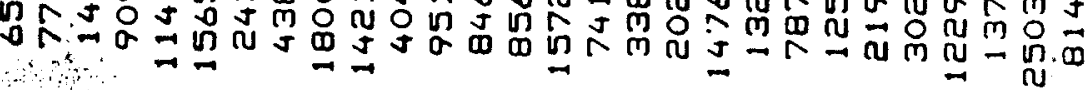

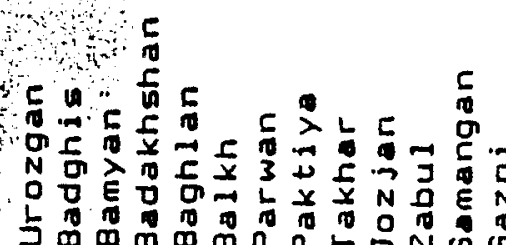

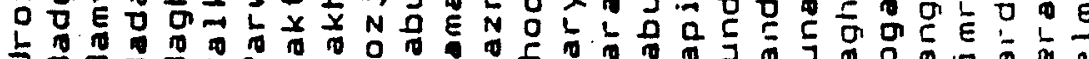

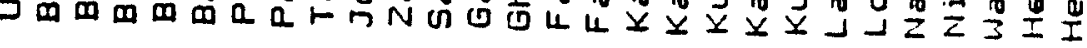

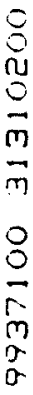

m

$\dot{0}$

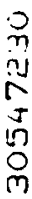

$\stackrel{\circ}{m}$ 옹

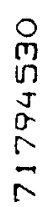


gi

$\because \pi E$

a. 1 .

-1 त 0

$0.0 \%$

(t) ก

$\sim 2$

U U U

ก... ก

0 J

(4) ก 0

แ) $\cup$

$\omega \circ \omega$

000

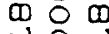

vo

a.

- o u

$\checkmark Q V$

. 0.

$-00$

$\begin{array}{ll}\overrightarrow{0} & \overrightarrow{0} \\ 0 & 0 \\ \overrightarrow{0} & 0 \\ \omega & \vec{\omega} \\ 0 & 0\end{array}$

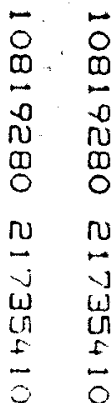

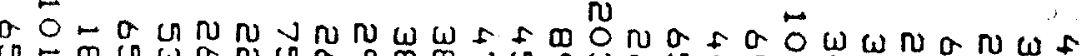

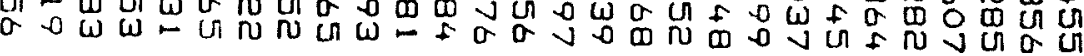

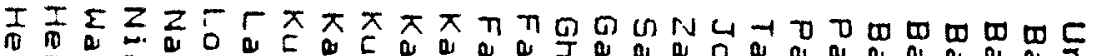
= a

3

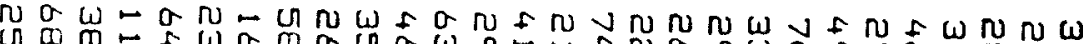
U जिए

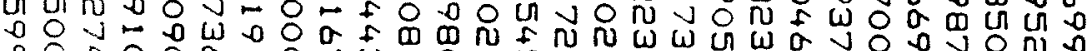

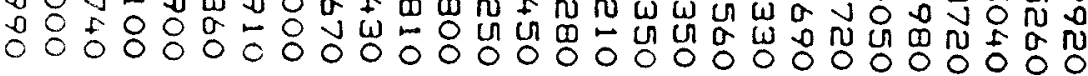

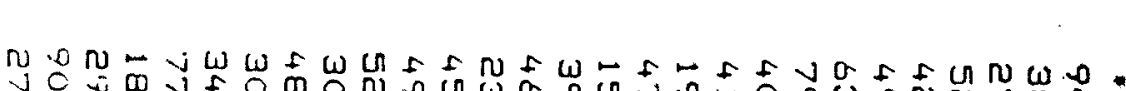

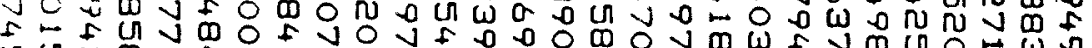

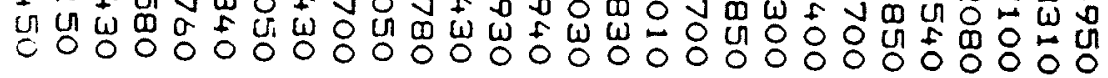

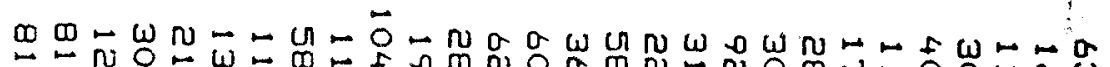

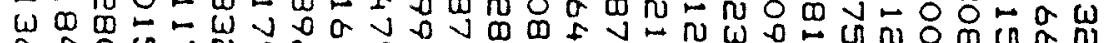
a f 0 u $v$ N 0 a

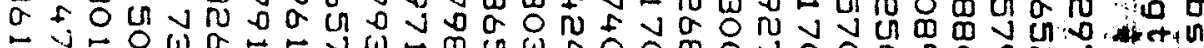

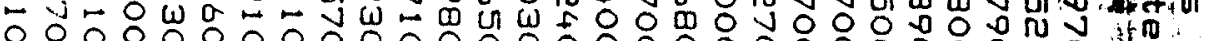

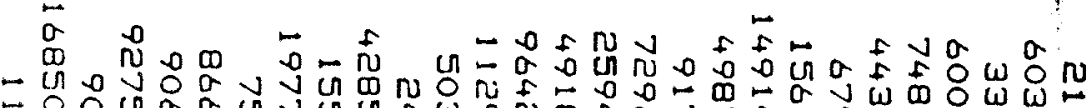
- OOU U U U U U

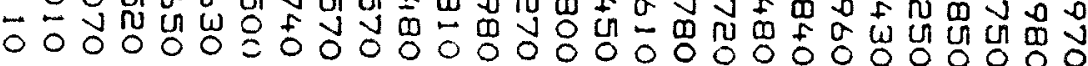

๓ Un

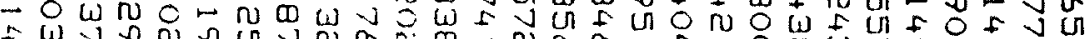

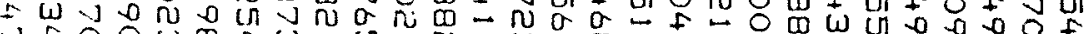
U.

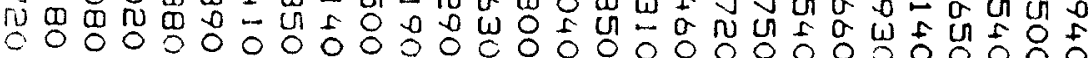
(1)

$2 \cos 20$

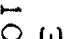
0 U

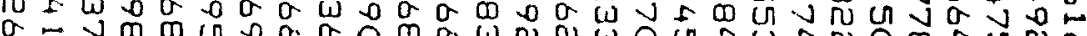
a $\overrightarrow{0}$ ए

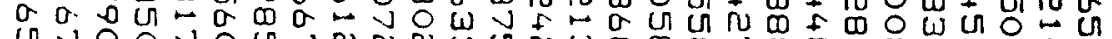

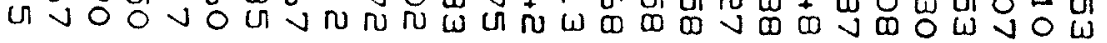

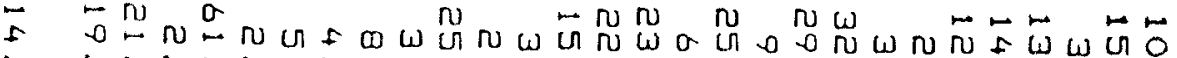

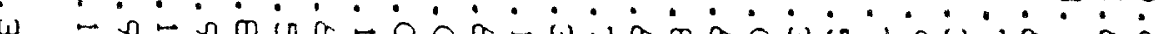
a

$0-000000000000000000000000000$

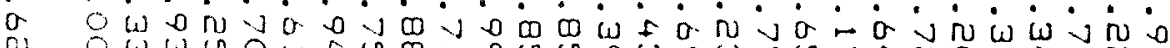

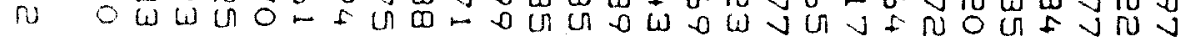

$\begin{array}{ll}0 & \\ 7 & \\ 0 & \\ 5 & \\ 0 & \\ 0 & \end{array}$

$<\frac{Z}{0}$

$\infty$

un

2

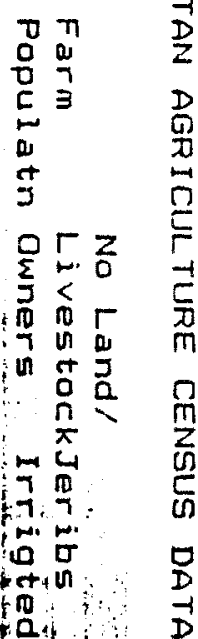

104

$17 \frac{1}{1}$

年

吉 Un $^{\prime}$

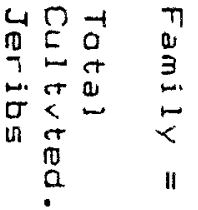

$\pi \pi$

$\stackrel{01}{2}$

要

מ.

$\pi \backsim D$

Q $12<$

370

in.

$<$ Un

$\rightarrow C$

77

ด

$+\sigma 0$

ก 1 5

0 


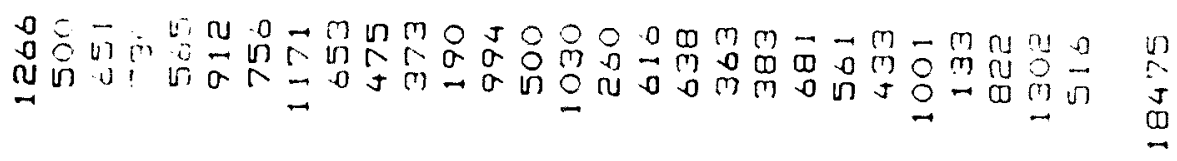

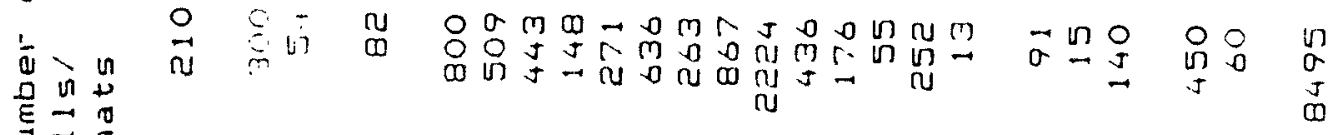

$\sum_{2} \frac{\overrightarrow{0}}{3} \frac{1}{4}$

点

$\sum_{4}^{5} \frac{1}{x}$

。

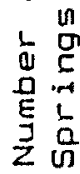

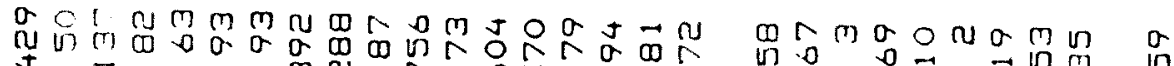

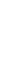

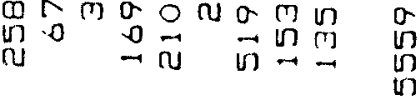

4

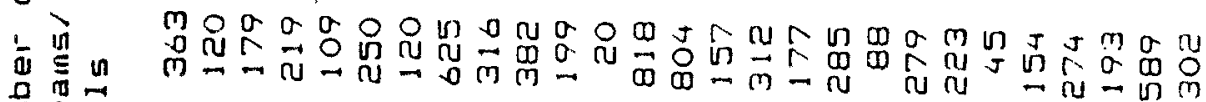

है

$\sum \frac{1}{2} \frac{c}{\pi}$

in

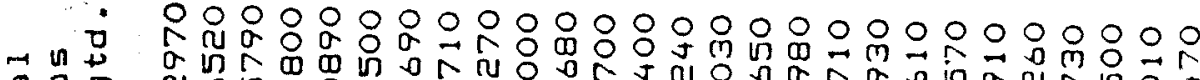

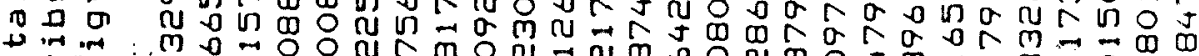

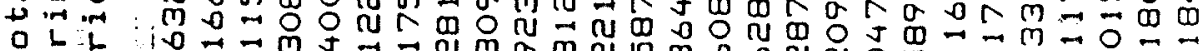

这故

17 .

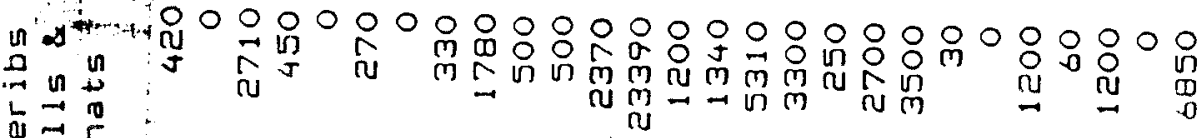

$\frac{\mathrm{d}}{3} \frac{1}{6}$

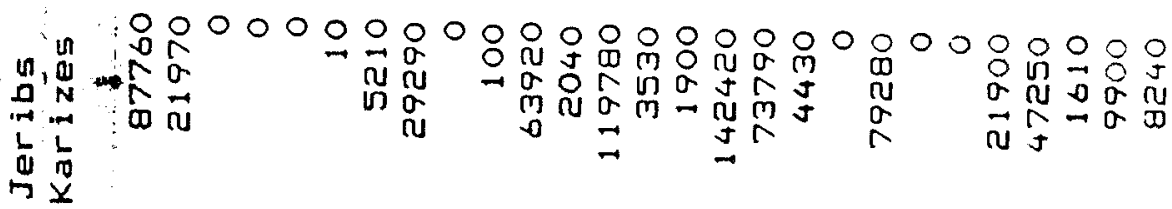

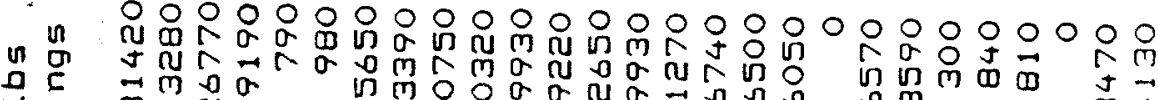

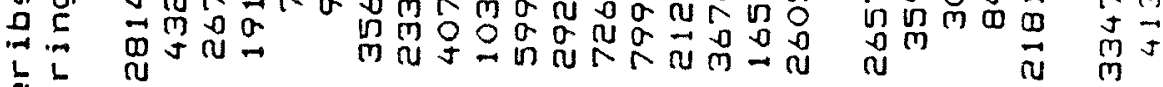
$\frac{1}{\square} \frac{1}{2}$

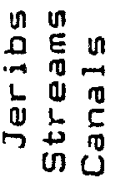

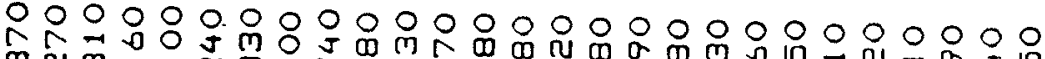

mญ

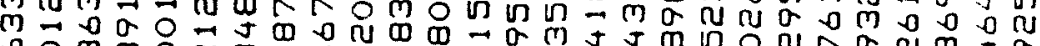

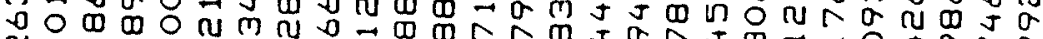
ญ

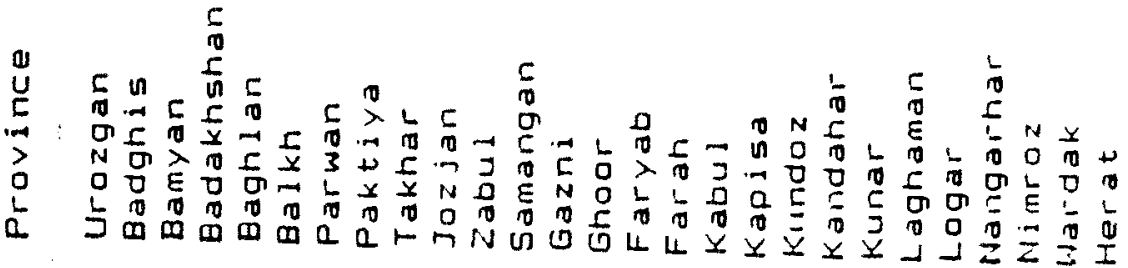

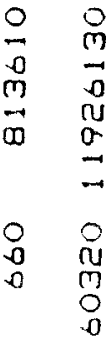

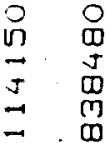

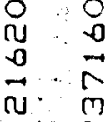

0
0
$\frac{1}{2}$
$a$

$\begin{array}{lll}0 & 0 \\ 0 & 0 & 0 \\ 0 & 0 & 0 \\ 0 & 0 & 0\end{array}$

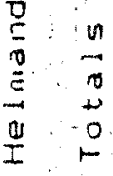




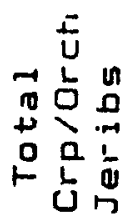

$\stackrel{\text { in }}{n}$ in

ว

$1 \frac{1}{4} \frac{1}{4}$

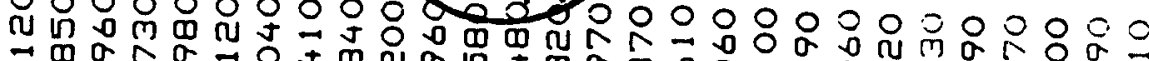

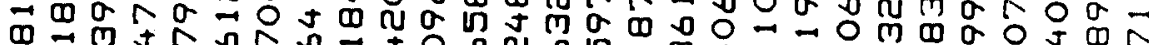

บ 0 m $\rightarrow a \rightarrow 0$

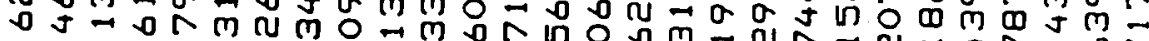
$m$ M

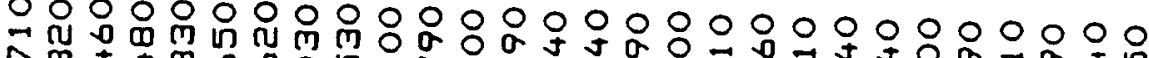

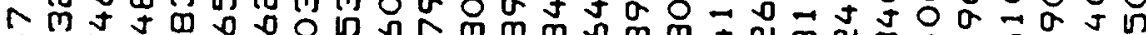

ง

$\rightarrow$ บ ญ กิ

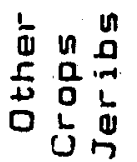

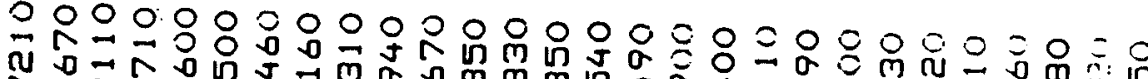

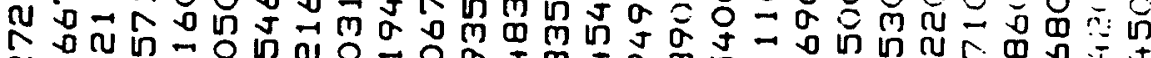

บ

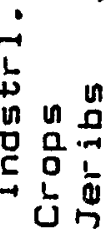

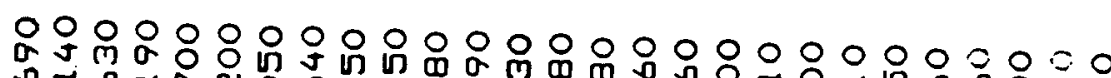

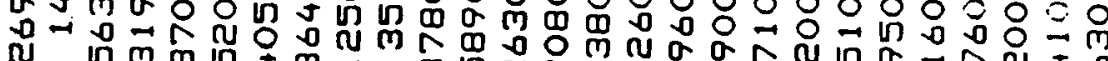

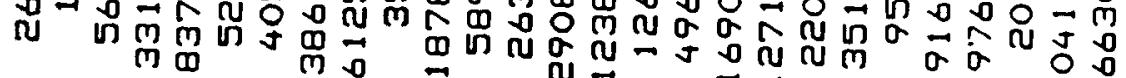

in

ก $\rightarrow \rightarrow$

$\Upsilon \mathrm{N}$

0
0
0
0
0

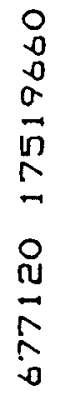

is

$\begin{array}{lll}\text { a } & \text { n } \\ \text { on } & 0 & 0 \\ 0 & 0 & 1 \\ 0 & 0 & 0\end{array}$

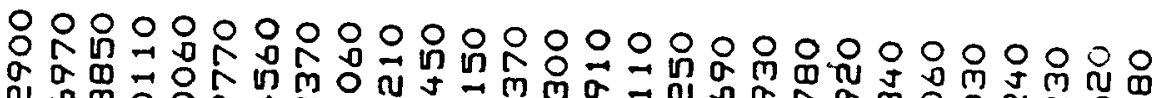

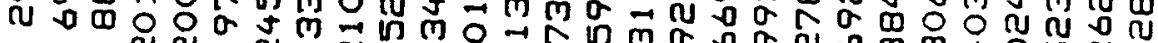

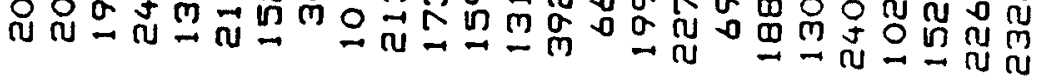

$\stackrel{\text { กิ }}{\text { ถั }}$

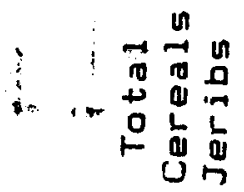

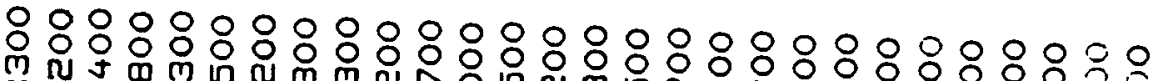

m ñ

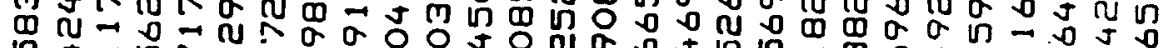

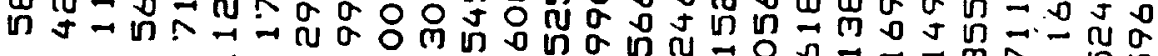

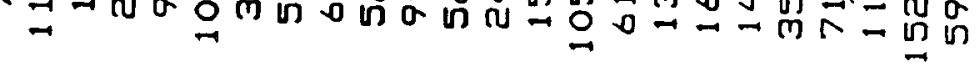

0
บn
0

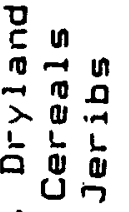

$\dot{t}$ in

$\operatorname{lom}_{\rightarrow} \ln$

$\rightarrow \pi$ D

L $\boldsymbol{x} \rightleftharpoons$

$\leq \frac{1}{0} \frac{1}{0}$

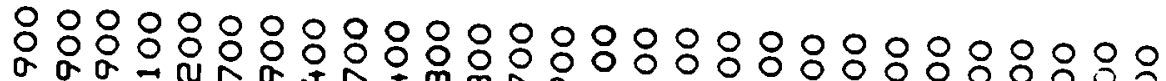

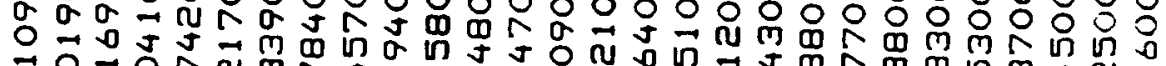

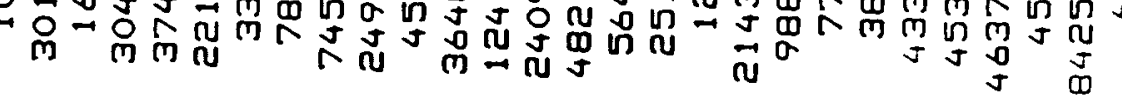

0
0
0
0
0
0
0
0
0
0
0
5
ก

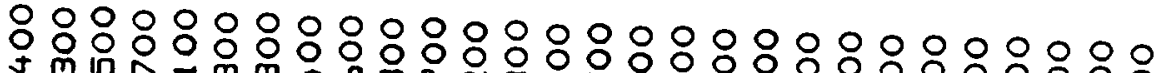

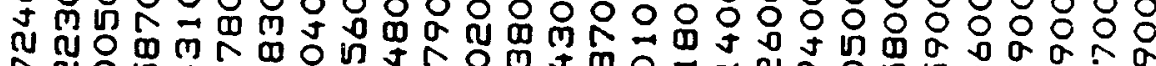

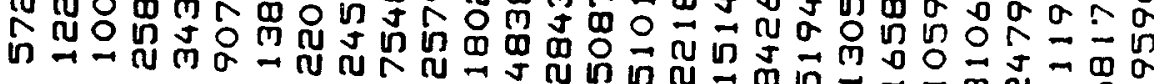

$\stackrel{0}{\stackrel{0}{C}}$

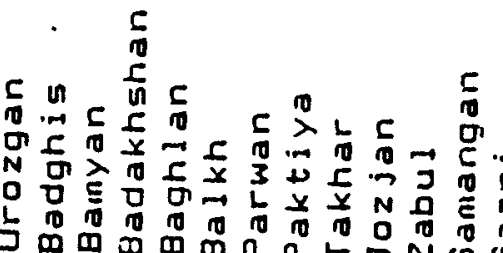

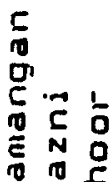

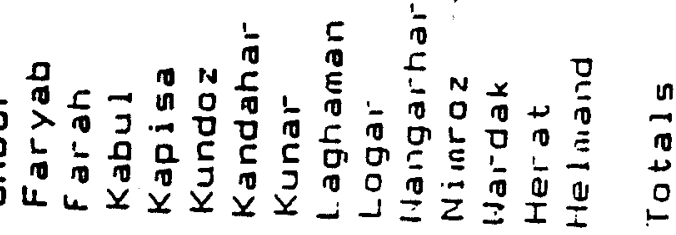

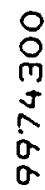

